\title{
How Network Television Coverage Of the President and Congress Compare
}

\author{
A vailability of live coverage \\ of House does not seem \\ to have led to more network \\ coverage. President still \\ dominates network news.
}

- While the U.S. Constitution established the legislative and executive as co-equal branches of government, since the end of the 19th century that balance has increasingly tilted toward the president. With the advent of television, the disparity between the ability of the president and the ability of the Congress to communicate directly with the American people has become more evident. ${ }^{1}$

There is considerable reason to believe that this disparity greatly favors the president. Former U.S. Senator J. William Fulbright claimed that the president's ability to use television had done as much to expand the powers of his office as a consti-

\footnotetext{
I Newton Minow, John B. Martin and Lee M. Mitchell, Presidential Television (New York: Basic Books, 1973); Denis Rutkus. A Report on the Simultaneous Television Network Coverage of Presidential Addresses to the Nation (Washington, D.C.: Library of Congress, 1976).

2 U.S. Senate. Committee on Commerce, Subcommittee on Communications, Hearings on Senate Joint Resolution 209.9 lst Cong., 2nd Sess., 1970.

'Rutkus, op. cil.; Timothy R. Haight and Richard A. Brody. "The Mass Media and Presidential Popularity." Communicafion Research, 4:41-60 (January. 1977).

+ Michael B. Grossman and Martha J. Kumar, Portraping the Presiden ( Baltimore: John Hopkins University Press. 198I), pp. 239-40. 253-67.

'Herbert Gans, Deciding Whar's News (New York: Pantheon Books. 1979),

" Edward 3. Epstein. New's,from Now'here (New York: Vintage Books, (97).

' Michael J. Robinson and Kevin R. Appel, "Network News Coverage of Congress," Political Stience Quarterly: 94:407-18 (Fall, 1979).

"Robert $O$. Blanchard. Congress and the News Media (New York: Hastings House, (974).
}

tutional amendment. ${ }^{2}$ Public support for the president and his policies has consistently risen after major speeches on network television. ${ }^{3}$ While few news sources can obtain network access on a regular basis, at least one story about the president is automatically carried most days on all three networks. Grossman and Kumar have argued that the president's interactions with the press are of primary importance in portraying his image to the public, and their analysis shows that a president can count on substantial favorable coverage both in the print and broadcast redia. ${ }^{4}$ Gans has even maintained that proximity to the presidency is a ticket to newsworthiness for second and third-tier news sources, ${ }^{5}$ and Epstein has insisted that network producers have established a de facto pecking order for news priorities which places presidents first, senators in the middle and House members last. ${ }^{6}$

If the president dominates the executivelegislative race for news coverage, the Senate similarly overshadows the House. In the only major study to date of congressional coverage, Robinson and Appel found the ratio of the Senate to House stories on network television news to be nearly two-to-one. ${ }^{7}$ This is hardly surprising since Blanchard has reported that far more news media resources are devoted to Senate than House coverage. ${ }^{8}$ Political

\footnotetext{
- Lynda Lee Kaid is associate professor of communication at the University of Oklahoma. Joe Foote is administrative assistant to U.S. Representative David McCurdy. An earlier version of this paper was presented at the International Communication Association Convention, Minneepolis. 1981. The authors wish to express their appreciation to Greg Givens and Jan Hunter for their assistance with this project.
} 
scientists have ascribed this coverage disparity to the smaller size of the Senate, its platform for presidential hopefuls and the visibility of senators from larger states. ${ }^{9} \mathrm{~A}$ more thorough investigation, using content analysis of media coverage in path models predicting coverage of senators in the 83rd, 89th, 91 st, and 93rd Congresses, suggests that other factors may be at work. Weaver and Wilhoit found that, while staff size, state size, seniority and committee leadership positions appear to be important explanations of AP wire coverage, the greatest predictor of senatorial visibility was the quantity of an individual senator's activities. 10

For many years observers argued that opening up the House of Representatives to live coverage of floor proceedings might help redress the imbalance in coverage between the House and other executive and legislative bodies." Although such live coverage has been available since March of 1979, no studies have considered the impact of this increase availability.

Even when congressional stories, whether House or Senate, survive the rigid filtering process imposed by the newsgathering system, exposure does not guarantee favorable coverage. Robinson and Appel, after examining network coverage for five weeks, coded $84 \%$ of the stories as neutral and $16 \%$ as negative. None of the stories was considered to have a positive slant. ${ }^{12}$ This pattern seemed to be constant across all three networks. In a survey of House members. Foote found that congressmen are not in disagreement, believing overwhelmingly that network coverage is inadequate, superficial and negativistic. ('ongressmen expressed confidence in neither the networks' ability to understand the intricacies of the legislative process nor their aptitude for pursuing story lines that involved complex issues. ${ }^{13}$

In response to issues discussed above, the content analysis reported here considered the following research questions:

1) How does network news coverage of the president differ from coverage of the House and Senate in terms of number of stories, time devoted to the stories, placement of the stories, and use of film within the stories?

2) What differences exist among networks in such coverage?

3) What difference has opening floor proceedings of the House of Representatives made to media exposure of that body?

\section{Method}

This content analysis of network television evening news, using Vanderbilt University's Television News Index and $A b$ stracts, covered six months of network evening news. The six months included the three month period of April, May and June of 1977 and the three month period of April, May and June of 1979. The separateyear, three month samples were drawn for four reasons: 1) 1977 and 1979 were both First Sessions of the 95th and 96th Congresses, respectively, and therefore comparable in their patterns of legislative development; 2) neither year was an election year, allowing maximum examination of non-electoral and non-campaign events; 3) April, May and June are traditionally months of intense legislative activity and in off-election years are more immune to campaign influences than months later in the year; and 4) the House opened its floor proceedings to cameras for the first time in March of 1979; thus the two year sample would provide comparable periods of coverage before and after that event.

This six-month period yielded 1,123 items which focused on the president, the Senate, the House or some combination thereof. Several categories were used by the coders. In addition to coding the date of each story, coders recorded the following data on each item:

Network: ABC, CBS, NBC

Placement: broken down into 7-minute intervals

\footnotetext{
J. S. Saloma. Congress and the New Politics (Boston: LittleBrown. 1969).

Iv David H. Weaver and G. Cleveland Withoit. "News Media Coverage of U.S. Senators in Four Congresses, 1953-1974," Journalism Monographs No. 67. April, 1980.

1 U.S. Congress. Joint Committee on Congressional Operations. A Clear Message to the People (Washington. D.C.: Government Printing Office. Report No. 94-539, 1975).

12 Robinson and Appel, op. cit.

13 Joe S. Foote. "Coorientation in the Network Television News processing System: Coverage of the United States House of
} (Footnote continued) 
TABLE 1

Coverage of the President and Congress

President

Senate

$2.6 \mathrm{~min}$.

$1.6 \mathrm{~min}$.

per storya

Placement $^{\mathrm{a}}$

Ist $7 \mathrm{~min}$.

2nd $7 \mathrm{~min}$

$46.9 \%$

$26.2 \%$

$14.6 \%$

$12.2 \%$

4th $7 \mathrm{~min}$.

Filma

No

$33.5 \%$

$66.5 \%$

588
$54.5 \%$

$24.6 \%$

$31.6 \%$

$27.5 \%$

$16.4 \%$

$45.5 \%$

244
House

$1.6 \mathrm{~min}$.

$28.5 \%$

$33.3 \%$

$24.2 \%$

$14.0 \%$

$47.8 \%$

$52.2 \%$

207
Combination

$2.3 \mathrm{~min}$.

$42.9 \%$

$29.8 \%$

$16.7 \%$

$10.7 \%$

$46.4 \%$

$53.6 \%$

84

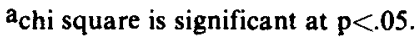

Participants: seven categories were possible here-the president, the Senate, the House, the president and the Senate, the president and the House, the House and the Senate, a combination of all three

Primary focus: President, Senate, House, combination

Film: film used or not used

Time constraints and the large number of items did not permit each item to be coded by multiple coders, resulting in a comprehensive intercoder reliability computation. However, in a preliminary pilot exercise, coders completed a sample set of the data with agreement on $87 \%$ of the category codes for the stories in the sample set.

\section{Results and Discussion}

Coverage of the President and Congress: Throughout the six-month period (three months in 1977 and three months in 1979) we located 1,123 stories which focused on the president, Congress or some combination. Table 1 presents the findings accord. ing to the categories used in coding the data.

Representatives." Unpublished doctoral dissertation, University of Texas at Austin, 1979.
As has been the case in previous studies, the president clearly dominates the network coverage. Overall, the president was the primary focus of 588 stories $(52.3 \%)$, while the Senate was the focus of 244 $(21.7 \%)$ stories, the House was featured in $207(18.4 \%)$, and 84 stories $(7.5 \%)$ were combinations. Since the combination category accounted for such a small percentage of the stories, this category was not considered in the remainder of the analysis.

The president not only received more coverage in terms of story quantity, but also received more coverage in terms of total time. Stories about the president totalled 25.10 hours, but the Senate coverage was only 6.51 , and the House coverage was 5.49. The average time of a story about the president was 2.6 minutes, considerably higher than the average 1.6 minutes devoted to each story about the Senate or House.

Stories about the president were also placed earlier in a newscast. Almost half $(46.9 \%)$ of all stories about the president occurred in the first seven minutes of the newscast. Congress could expect much less desirable placement. Most stories about the Senate and House were placed in the second seven miqutes, and a substantial 
TABLE 2

Comparison of Networks, in Percent

$\begin{array}{lccc} & \text { ABC } & \text { CBS } & \text { NBC } \\ \text { Focus } & & & \\ \text { President } & 55.0 \% & 50.9 \% & 51.6 \% \\ \text { Senate } & 18.6 & 23.4 & 22.6 \\ \text { House } & 19.5 & 18.0 & 7.9 \\ \text { Combination } & 6.8 & 7.7 & 7.9 \\ \text { Story Time } & & & \\ \text { 0-1 min. } & & & \\ \text { 1-2 min. } & 31.3 & 35.1 & 27.9 \\ \text { 2-3 min. } & 23.0 & 24.3 & 28.4 \\ 3 \text { min. and over } & 20.7 & 20.9 & 23.2 \\ \quad \text { N of Stories } & 24.9 & 19.6 & 20.5 \\ \quad & 338 & 444 & 341\end{array}$

President

Placement

1 st $7 \mathrm{~min}$.

2nd $7 \mathrm{~min}$.

3rd $7 \mathrm{~min}$.

46.8

45.8

48.3

22.0

27.6

29.0

4th 7 min.

18.3

13.8

12.9

11.9

12.9

10.8

Film

No

37.6

32.9

29.5

Yes

62.4

70.5

$\mathrm{N}$ of Stories

186

176

\section{Senate}

\section{Placementa}

1 st $7 \mathrm{~min}$.

2nd $7 \mathrm{~min}$.

3rd $7 \mathrm{~min}$.

4 th 7 min.

Film

$$
\begin{aligned}
& \text { No } \\
& \text { Yes } \\
& \text { N of Stories }
\end{aligned}
$$

\section{House}

\section{Placement}

1 st $7 \mathrm{~min}$.

2nd $7 \mathrm{~min}$.

3rd $7 \mathrm{~min}$.

4th $7 \mathrm{~min}$.
33.3

24.2

25.8

16.7
22.5 
Film

No

Yes

$\mathrm{N}$ of Stories
45.5

54.5

66
55.0

45.0

80
41.0

59.0

61

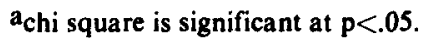

number of stories were buried in the final 14 minutes.

The president dominated most other categories as well. For instance, two-thirds of all stories about the president contained film as part of the coverage. However, just barely over half $(52.2 \%)$ of stories about the House, and only $45.5 \%$ of Senate stories were accompanied by film.

This study clearly reaffirms the dominance of the president of the United States over the House and Senate in terms of network television evening news exposure. When one officer of the government receives more than twice as much network air time over a six-month period than his two legislative counterparts put together, has access to stories that are $40 \%$ longer, secures "top of the book" coverage nearly twice as often, and is given film coverage of his activities two-thirds of the time, his media superiority becomes apparent.

This pattern of presidential dominance in network news could have an effect on the viewer's perceptions of national events. Because the public is accustomed to seeing the most important news first in a newscast, one could infer that those who dominate the top of the newscast are more important participants in our governmental system than those who occupy lesser status in news broadcasts. That such dominance in terms of coverage can be important to public perceptions is well documented by the findings of Singleton 14 and Haight and Brody's that favorable coverage for the president results in higher popularity ratings in opinion polls. While the president is indeed the chief figure in our tri-partite system and merits considerable

\footnotetext{
"A Donald L. Singleton. "The Role of Broadcasting in Presidential Popularity: An Exploration in Presidential Power." Unpublished doctoral dissertation. University of Oklahoma. 1977.

is Haight and Brody, op. cit.
}

media exposure, his network news dominance severely limits the television options of the 535 members of the Congress acting as representatives of a co-equal branch.

Comparing Networks: Comparisons of the coverage of the three networks in Table 2 revealed very few differences in patterns of coverage of the president and Congress. CBS seemed to devote more stories to Congress, particularly the Senate, than did the other two networks. This difference, however, is probably a result of the slightly higher number of total stories appearing on CBS, since the chi square distribution was not statistically significant.

The results were basically the same when network coverage of the president, Senate and House were considered separately. On stories about the president, the networks did not differ significantly in their story placement or number of stories using film. Stories about the Senate did not vary significantly among networks in terms of film usage, but there were significant differences in terms of placement. NBC placed stories on the Senate earlier (first seven minutes of newscast) than did the other networks. $A B C$ tended to place such stories later-i.e. more $A B C$ stories on the Senate occurred in the last seven minutes than was the case for the other two networks. No network differences in the placement, or film usage were apparent for the stories on the House.

Those espousing the "mirror theory" of network news would interpret these marked similarities as a healthy conformity based on "what is news" as seen by objective journalists at work. Organizational theorists, however, might use these figures to substantiate their claim that television news is produced through a series of defined processes which routinize newsgathering and reduce uncertainty in the newsprocessing system. From this semi-indus- 
TABLE 3

Comparing Coverage in 1977 with 1979

President

1977
1979

$32.4 \%$

$38.3 \%$

$29.3 \%$

13.84

Time (hrs)

10.46

Placement
1 st $7 \mathrm{~min}$.

$$
54.7 \%
$$

2nd $7 \mathrm{~min}$.

$27.3 \%$

3rd 7 min.

$11.6 \%$

4th $7 \mathrm{~min}$.

$40.5 \%$

$25.2 \%$

$17.1 \%$

$17.1 \%$

Film

No
Yes

$\mathbf{N}$ of Stories

$$
\begin{gathered}
21.8 \% \text { d } \\
78.2 \%
\end{gathered}
$$

267

$$
\begin{aligned}
& 43.0 \% \mathrm{~d} \\
& 57.0 \%
\end{aligned}
$$

Senate

1977
1979

1977
House

1979

Values with same superscript differ at $p<.05$.

$\begin{array}{lccc}17.6 \% & 29.4 \% & 28.4 \% & 34.8 \% \\ 48.6 \% & 40.0 \% & 43.2 \% & 34.8 \% \\ 33.8 \% & 30.6 \% & 28.4 \% & 30.4 \% \\ 1.39 \mathrm{a} & 5.12^{\mathrm{a}} & 2.09 & 3.40\end{array}$

trial process would come a news product influenced by organizational constraints, accounting for many inter-network similarities in news content.

Comparing 1977 and 1979. As indicated earlier, one of the major reasons for using both 1977 and 1979 was a desire to determine if live coverage of the House of Representatives, which began in the intervening time, had affected the exposure received by the House in network evening newscasts. However, the Senate and the president are considered, as well, in order to provide a basis of comparison.

As Table 3 indicates, 1979 increased coverage for all three categories. The President received $20 \%$ more stories in 1979 than in 1977. The largest increases were for the Senate. The number of stories devoted to the Senate more than doubled, increasing from 74 in 1977 to 170 in 1979. The amount of time devoted to these stories nearly tripled, from 1.39 hours in 1977 to 5.12 hours in 1979. This increase was almost exclusively a result of increased stories about "individual senators." This type of item merited only 16 stories in 1977, but there were 106 such stories in 1979.

The number of stories about the House of Representatives increased also, but the increase of $18 \%$ was not nearly as great as the $130 \%$ increase for the Senate. The number of stories about the House increased from 95 to 112 , and the amount of time devoted to these stories increased from 2.09 to 3.40 . The president received additional coverage in 1979 , but the increase from 1977 was only $20 \%$. Clearly, however, the live coverage of the House proceedings does not appear to have resulted in substantially more stories in 1979. The time devoted to a story about the House did increase, however. The average story in 1977 was only 1.32 minutes long, while the average story in 1979 was $\mathbf{1 . 8 2}$.

There were significant differences in 
story placement in all three categories. The president received fewer stories in the first 7 minutes in 1979 than he did in 1977. The Senate on the other hand, did significantly better in placement in 1979. The House fared less well. The significant difference here was that the House got fewer stories in the first 7 minutes and considerably more in the last 7 minutes in 1979 than was the case in 1977.

Differences in film usage were also apparent. Stories about the president contained significantly less film in 1977 than in 1979. In $1977,78.2 \%$ of all stories about the president contained film, but this was true for only $57.0 \%$ in 1979 . No significant difference was present in film usage in stories about the Senate, but stories about the House benefited from film significantly more in 1979 than in 1977. In 1977, only $44.2 \%$ of stories about the House used film, but $58.9 \%$ contained film in 1979 .

Given the overall presidential dominance of news coverage it seemed important to analyze other aspects of the relationships in coverage of the two branches. In addition to the increased coverage accorded senators as prospective presidential candidates, this study found that regular House and Senate legislative coverage improved in terms of placement and film coverage when the subject matter involved the president in some way. Using the "participants" category, we found that stories about the House and/or Senate which also included the president received placement in the first seven minutes of newscast $47.8 \%$ of the time. Story time was also longer $(2.59 \mathrm{~min}$ utes) than the average Senate or House story, and film was used $66 \%$ of the time. Thus, it would appear that proximity to the president, interest in the presidency, or conflict with the president can be a passport to greater network exposure.

\footnotetext{
is Foote, op. cit.
}

Some additional facts of interest emerged when the types of coverage given the two branches were compared. The president, himself, was the main subject of most stories focusing on the executive branch of government. However, coverage of the House was much more likely to stress congressional committee hearings and action than House leaders. Such coverage made up almost $50 \%$ of all coverage given to the House across both years studied here.

In conclusion, it is difficult to understand the lack of increased coverage afforded the House after televised proceedings began, particularly as this would have provided an important source of all-important video/film segments for use on the evening news. For whatever reasons, it appears that the television networks did not take advantage of this opportunity. In fact, only a handful of occasions were noted in which a network actually used any of this footage from the daily House proceedings.

Perhaps some of the difficulty lies in the types of congressional activities upon which the media have traditionally focused. The media (and many other observers) have traditionally assumed that most of the important activities of the legislative branches occur in committees or hearings, rather than on the floor itself.

One final explanation might account for the failure to uncover any significant increase in coverage between 1977 and 1979. There was considerable initial resentment on the part of the networks, which had originally objected to not having greater control of the coverage placed in their own hands. ${ }^{16}$ Such concerns may have caused the networks to treat the coverage as less important initially. The passage of time may have rendered these attitudes less prominent, and additional research of later time periods may prove more fruitful. 